\title{
State level water security indices in Mexico
}

\author{
Felipe I. Arreguin-Cortes ${ }^{1}$, J. Raul Saavedra-Horita ${ }^{2}$, J. Manuel Rodriguez-Varela ${ }^{3}$, Velitchko G. Tzatchkov ${ }^{3^{*}} \mathbb{D}$, \\ Petronilo E. Cortez-Mejia ${ }^{3}$, Oscar J. Llaguno-Guilberto ${ }^{3}$ and Arizabeth Sainos-Candelario ${ }^{3}$
}

\begin{abstract}
Background: As tends to be the case in large, developing countries, Mexico is a nation of notable meteorological, hydrographic and social contrasts throughout its territory, which impact the various population strata in different ways. The public administration in Mexico is divided into federal (nationwide), state and municipal levels. In this sense, it is desirable to have water security metrics not only for the country as a whole but also for each state. The current paper seeks to show how these contrasts create different water-security scenarios using pertinent indices. This is particularly relevant for large countries such as Mexico, with approximately two-thirds of its territory in arid or semiarid areas, which face natural water scarcity, and only one-third has a very high relative water abundance.

Results: The concept of the global water security index was adapted to the state level in Mexico and calculated for each Mexican state in accordance with the worldwide analysis methodology proposed by other authors, which considers water availability, accessibility, safety and quality, as well as management. The proposed methodology was applied in a geographic information system environment, and it was used to obtain water security indices for all Mexican states. The states in which the situation was found to be critical, according to the computed global index, are Sonora, Baja California and Guanajuato, followed by Mexico City, Colima, Aguascalientes and Sinaloa.

Conclusions: Although the vast majority of the most vulnerable states and municipalities that have the highest drought risk are located in the north of the country in the Mexican highlands, even southern states such as Guerrero, Oaxaca, Chiapas, and Tabasco (which are typically characterized as rainy) have municipalities with a high drought vulnerability degree and are also severely affected by this phenomenon, especially in those years in which El Niño manifests itself, as was the case in 2015. The proposed methodology may serve as an example of how to assess water security using mainly free and officially published information, combined with international comparative country information, especially for countries where such information is limited.
\end{abstract}

Keywords: Water security, Water availability, Access to water, Water management, Water resources in Mexico

\section{Introduction}

Several definitions have been proposed for the concept of water security by different authors [1-9], and various methodologies have been employed to express the concept of water security via indices. As a common denominator, the proposed definitions and their related methodologies consider the availability and access to an adequate quantity and quality of water for the population and industry, along with an acceptable level of risk

\footnotetext{
* Correspondence: velitchk@tlaloc.imta.mx

${ }^{3}$ Mexican Institute of Water Technology, Paseo Cuauhnahuc 8532, Col.

Progreso, 62550 Jiutepec, Morelos, Mexico

Full list of author information is available at the end of the article
}

from the impacts of hydrometeorological extremes and environmental deterioration. Among these methodologies, [3] proposed a global water security index (GWSI) to measure water security according to goal 6 of the 17 global goals for sustainable development established by the United Nations [10], namely, to ensure access to water and sanitation for all. The GWSI is comprised of the following four criteria: availability, accessibility to services, safety and quality, and management.

The index proposed by [3] is applied at the global (world) level, with country-scale data, transboundary river basin data, or data gathered from digital maps at a low spatial resolution $\left(0.5^{\circ}\right)$, while the aggregated results

(c) The Author(s). 2020 Open Access This article is licensed under a Creative Commons Attribution 4.0 International License, which permits use, sharing, adaptation, distribution and reproduction in any medium or format, as long as you give appropriate credit to the original author(s) and the source, provide a link to the Creative Commons licence, and indicate if changes were made. The images or other third party material in this article are included in the article's Creative Commons licence, unless indicated otherwise in a credit line to the material. If material is not included in the article's Creative Commons licence and your intended use is not permitted by statutory regulation or exceeds the permitted use, you will need to obtain permission directly from the copyright holder. To view a copy of this licence, visit http://creativecommons.org/licenses/by/4.0/. 
Table 1 Global water security index definition and data sources

\begin{tabular}{|c|c|c|c|}
\hline $\begin{array}{l}\text { Criterion for } \\
\text { water security }\end{array}$ & Indicators & Spatial and temporal scales & Definition and data sources \\
\hline \multirow[t]{3}{*}{ Availability } & WSI & $\begin{array}{l}\text { Spatial resolution: } 0.5^{\circ} \text {; median } \\
\text { monthly values for } 2010\end{array}$ & $\begin{array}{l}\text { WSI is defined as the relation between the total } \\
\text { water withdrawal and availability. Source: }[11]\end{array}$ \\
\hline & Drought indicator (DI) & $\begin{array}{l}\text { Spatial resolution: } 0.5^{\circ} \text {; annual values } \\
\text { for } 2012\end{array}$ & $\begin{array}{l}\text { DI is calculated using hydrological model PCR-GLOBWB. } \\
\text { Source: [12] }\end{array}$ \\
\hline & Groundwater depletion & $\begin{array}{l}\text { Spatial resolution: } 0.5^{\circ} \text {; annual values } \\
\text { for } 2010\end{array}$ & $\begin{array}{l}\text { Depletion is calculated using hydrological model PCR-GLOBWB. } \\
\text { Source: [13] }\end{array}$ \\
\hline \multirow[t]{2}{*}{$\begin{array}{l}\text { Accessibility to } \\
\text { services }\end{array}$} & Access to sanitation & Country-scale data for 2014 & $\begin{array}{l}\text { Percentage of the population with access to sanitation. } \\
\text { Source: [14] }\end{array}$ \\
\hline & Access to drinking water & Country-scale data for 2014 & $\begin{array}{l}\text { Percentage of the population with access to drinking water. } \\
\text { Source: [14] }\end{array}$ \\
\hline \multirow[t]{2}{*}{ Safety and quality } & Water quality index & Country-scale data for 2012 & $\begin{array}{l}\text { Includes } 4 \text { water quality parameters. } \\
\text { Source: [15] }\end{array}$ \\
\hline & Flood frequency index & Country scale data for 1985-2003 & $\begin{array}{l}\text { Flood frequency. } \\
\text { Source: [16] }\end{array}$ \\
\hline \multirow[t]{3}{*}{ Management } & World governance index & Country-scale data for 2010 & $\begin{array}{l}\text { Includes voice and accountability, political stability and absence } \\
\text { of violence, government effectiveness, regulatory quality, rule of } \\
\text { law, and control of corruption. } \\
\text { Source: [17] }\end{array}$ \\
\hline & $\begin{array}{l}\text { Transboundary legal } \\
\text { framework }\end{array}$ & Basin-scale data for 2015 & $\begin{array}{l}\text { Range of treaties per transboundary basin and their associated } \\
\text { risks of conflict. } \\
\text { Source: [18] }\end{array}$ \\
\hline & $\begin{array}{l}\text { Transboundary } \\
\text { hydropolitical tension }\end{array}$ & Basin-scale data for 2015 & $\begin{array}{l}\text { Level of tension in transboundary basins and the associated } \\
\text { risk levels. } \\
\text { Source: [18] }\end{array}$ \\
\hline
\end{tabular}

have a resolution of $5^{\prime}$ (approximately $10-15 \mathrm{~km}$ at the intermediate latitudes). Table 1 lists the criteria, indicators, scales, definitions and data sources used in [3]. This index is a good starting point for monitoring the progress towards the United Nations sustainable development goals and identifying strategies to improve the capability of nationwide as well as transboundary institutions. A higher spatial resolution is needed to define specific improvement needs and measures to be implemented within each country. However, this is particularly relevant for large countries such as Mexico, with approximately two-thirds of its territory in arid or semiarid areas, which face a natural water scarcity, while only one-third has a very high relative water abundance.

A watershed sustainability index, which integrates social, economic and environmental impacts using a pressure-state-response model, was proposed in [19] and applied to a $2200 \mathrm{~km}^{2}$ basin in Brazil, thereby obtaining a value of 0.65 , which represents an average sustainability value for the basin. Using a pressure-state-impact-response model, van Ginkel et al. [20] developed a dashboard of 56 indicators to establish a water security index and applied the index to ten cities. In their approach, the highest water security levels were obtained in wealthy cities in water-abundant environments, in which security is determined by the ability of the city to mitigate flood risks and to sustain the hinterland water supply dependency, as opposed to the lowest security in developing cities where the combination of high socioeconomic pressures (e.g., rapid population growth, slums, low GDP, and polluting industries) and inadequate responses (weak institutions and poor planning and operational management) leads to the inappropriate fulfilment of most functions of the urban water system.

Makin et al. [21] integrated an index that considers five water security dimensions, i.e., domestic, economic, urban, environmental and disaster resilience, and applied it to 7 countries in Asia and 13 countries in America, Africa and Europe, with no conclusive results. Shresthaa et al. [22] developed a water security index to characterize the actual field conditions using a model centered on household water-use behavior in urban areas of developing countries, which can be used to design policies and programs in small communities in such countries. Assefa et al. [23] noted that water security indices have been developed at the global, regional and country levels but that there is a clear absence of indices at the domestic level, considering the water supply, sanitation and hygiene. Using 12 indicators, they developed an index that was applied to the city of Addis Ababa, Ethiopia. The water supply dimension was found to be at a good level, whereas the sanitation and hygiene dimensions were poor and fair, respectively, concluding that the index can be a useful tool for water utilities.

The public administration in Mexico is divided into federal (nationwide), state and municipal levels. In this sense, 
it is desirable to have water security metrics not only for the country as a whole but also for the states. Several studies have been devoted to water security in Mexico. In [4], the trends of demographic growth, urbanization, demand for energy and food, climate change and water management in Mexico were analyzed, whereby recommendations were formulated with a particular focus on water security centered on the urgency of achieving good water management. Oswald Spring [24] examined water security in Mexico, based on social, political and economic aspects, with a focus on the national water law that favors participation in developing an integrated management model, which compares the current water use among different social and productive sectors. Arreguín-Cortes et al. [25] noted that Mexico faces various water security challenges, such as pollution, climate change, water scarcity, and management, and there exists the need to strengthen the water-related science and technology in Mexico. However, none of the authors above have defined and quantified specific water security indices.

In the current work, the GWSI concept proposed in [3] is adapted to the state level in Mexico as a first attempt to establish a benchmark using the standardized method to report and compare the annual performance with a definition of the components and common international and national terminologies. In this way, not only would nationwide (federal) stakeholders, water resources management practitioners and decision-makers benefit from such tools but also those at the state level. Another reason to develop state-level water security indices is information availability. Water governance in Mexico follows a by-river-basin-council model so that the information regarding water availability and management is generated within river basin boundaries and is normally more easily extrapolated to the state level.

\section{Methodology}

Mexico is a federation-type country composed of 32 states (the official country name is the United States of Mexico), with very heterogeneous climatic and hydrographic characteristics. For each of these state entities, as an initial approximation, the GWSI was calculated in accordance with the methodology proposed by [3], although the index was originally used at the global level. According to this methodology, the GWSI consists of the following four indices, each with its own weight: availability, $45 \%$; accessibility, $20 \%$; safety and quality, 20\%; and management, $15 \%$. Official Mexican statescale data were employed for the water availability, accessibility, safety and quality indicators, while the data for the management indicator were the same as those used in [3].

\section{Availability}

Water availability is determined according to scarcity (70\%), droughts (15\%) and groundwater depletion (15\%).

\section{Scarcity index}

The water scarcity index (WSI) is determined by the sustainable or renewable supply, the environmental flow requirements, and the demand for all purposes, such as public, urban, rural, industrial, agricultural, livestock and other purposes. The methodology uses WSI defined as the relationship between the total water withdrawal and available water, considering the environmental flow requirements (Eq. 1). The available water includes renewable groundwater. The withdrawal element includes surface and renewable groundwater that is used in agriculture and industry as well as in homes. Nonetheless, the use of nonrenewable groundwater, in other words, its overexploitation, is not included in the water withdrawal but rather in a separate indicator $[3,26]$.

$$
W S I=\frac{W_{w}}{A_{w}-E_{w}}
$$

where $W_{w}$ is the water withdrawal, $A_{w}$ is the water availability (renewable), and $E_{w}$ represents the environmental flow requirements.

In the previous equation, the environmental flow requirement $E_{w}$ is calculated as $Q_{90}$; in other words, the monthly stream flow that is exceeded $90 \%$ of the time. Although it is better to determine this element using the degree and nature of its dependency on the stream flow, such information is rarely observed directly [3]. This follows the application of low-flow hydrology methods to river ecology and environmental flow management studies [27], and the method to estimate the environmental volume on a global scale, as a percentage of the average annual runoff [28], is applied with the PCRaster GLObal Water Balance (PCR-GLOBWB) hydrological model [11].

To adapt the above at the state level in Mexico, the renewable water $A_{w}$ is considered to be the sum of the mean annual runoff $R_{w}$ and the average aquifer recharge $G_{w}$ [29]. Therefore, in its practical application, the environmental flow can be calculated as a certain percentage of the available renewable water $\left(\% A_{w}\right)$ or $\% R_{w}$. The WSI can only vary between 0 and $100 \%$ since the use of nonrenewable groundwater is not included in the water withdrawal.

In [28], $E_{w}$ is estimated as $27 \%$ of the mean annual runoff for central Mexico, 28\% for the Rio Grande basin, and $22 \%$ for north Mexico. The average $E_{w}$ value is $25.6 \%$, that is, $E_{w} \approx 0.256 R_{w}$. There are recent Mexican official data about the environmental flows $\left(E_{w}\right.$ as $\left.\% R_{w}\right)$ for some of the 37 hydrological regions (HRs) in the country and their basins, however, which are determined according to Mexican standard NMX-AA-159-SCFI2012 [30] establishing the environmental flow determination procedure in hydrological basins. These are HR 12 Lerma-Santiago [31], HR 14 Ameca River [32], HR 15 
Costa de Jalisco [33], HR 19 Costa Grande Guerrero [34], HR 20 Costa Chica de Guerrero [35], HR 25 San Fernando [36], HR 28 Papaloapan [37], HR 30 Grijalva [38], and the Golfo and Pacífico Rivers [39]. For those regions where such data were not found, an $E_{w}$ value of $30 \%$ was assumed, according to official Mexican recommendations [40] and the results from [28]. A matrix with the relationship between each of the Mexican states and each of the HRs was then obtained, and average values were calculated. For Tabasco, for example, an $E_{w}$ average of $55.6 \%$ was obtained, for Jalisco $48.9 \%$, for Guerrero $49 \%$, for Zacatecas $20.4 \%$, etc. These results were applied to $R_{w}$ for calculating the scarcity index. For 2015, at the country level, $R_{w}=354,990 \mathrm{hm}^{3}, G_{w}=91,788 \mathrm{hm}^{3}$, and $A_{w}=446,777 \mathrm{hm}^{3}$, so $G_{w} \approx 0.204 A_{w}[11]$.

\section{Drought index}

The drought index corresponds to hydrological droughts, according to the drought frequency and average frequency over a given period. To calculate the hydrological drought, the methodology uses the monthly 80th flow percentile, $Q_{80}$, that is to say, the mean flow that exceeds the monthly runoff $80 \%$ of the time [3]. In its application, a criterion can be used in which the drought index is determined by the percentage of drought-affected municipalities or by the percentage of state areas that was affected in the analysis period, in this case from 2003 to 2017.

In Mexico, the National Meteorological Service is the official agency of the federal government responsible for detecting the current status and evolution of drought through the Mexico Drought Monitor [41]. This monitor publishes monthly national maps of areas affected by drought, according to an intensity scale comprising abnormally dry (D0), moderate drought (D1), severe drought (D2), extreme drought (D3), and exceptional drought (D4).

Thus, based on the historical records of the Drought Monitor of Mexico (2003 to 2017) for each category of drought and municipal data, in this work, the drought hazard was determined by calculating the probability of drought occurrence (relative frequency) for each of the municipalities of Mexico, based on the methodology proposed by Ortega-Gaucin et al. [42], which consists of the following steps:

Step 1. Compilation of historical municipality records with at least $40 \%$ of their territory affected by any drought intensity or drought conditions, from D0 to D4.

Step 2. Obtaining the absolute frequencies corresponding to each type of severity of drought by municipality.
Step 3. Calculation of the drought probability by means of the envelope (D0 to D4), as the ratio between the number of months with drought and the number of records in the period.

Step 4. Classification of the probability of occurrence (degree of drought hazard). The probability values oscillate within the closed range of $[0,1]$. To classify these probabilities into percentiles with equal-sized categories, these values were adjusted to a normal distribution, and the result was multiplied by 100 to express them as percentages.

\section{Groundwater depletion}

Groundwater depletion is determined according to the natural recharge, the return flows from irrigation, and the annual groundwater extraction (for all purposes); if the annual groundwater extraction exceeds the natural recharge plus the runoff flows, this results in depletion. Depletion is calculated as the ratio between the extraction and natural recharge plus the return flows from irrigation, which can generate a value higher than 1 , so normalization is required. The normalization method, applied to the depletion values obtained from the extraction and recharge ratio from 0 to 1 , is the Min-Max method, as shown in Eq. 2 [43]:

$$
I_{q c}^{t}=\frac{x_{q c}^{t}-\min _{c}\left(x_{q}^{t_{0}}\right)}{\max _{c}\left(x_{q}^{t_{0}}\right)-\min _{c}\left(x_{q}^{t_{0}}\right)}
$$

where $I_{q c}^{t}$ is the normalized value of an individual indicator $q$ for a country (state) $c$ in a given time period $t$ and $x_{q c}^{t}$ is the gross value of the individual indicator $q$ for the country (state) $c$ in time period $t$, with $q=1, \ldots$, $Q$ and $c=1, \ldots, M$.

\section{Water access index}

In this index, access to drinking water carries a weight of $60 \%$, while access to sanitation has a weight of $40 \%$ [3]; see Eq. 3:

$$
\left.I_{\text {Acce }}=(0.6 \text { water })+(0.4 \text { sanitation })\right)
$$

\section{Water quality and protection against flooding Water quality index}

To calculate this index, the methodology proposed by [3] uses the following five water quality parameters:

- Dissolved oxygen (DO) $[\mathrm{mg} / \mathrm{L}]$

- Electrical conductivity [microsiemens/cm]

- $\mathrm{pH}$ [unitless]

- Total phosphorous (P) $[\mathrm{mg} / \mathrm{L}]$

- Total nitrogen $(\mathrm{N})[\mathrm{mg} / \mathrm{L}]$ 
These parameters arose from consultations with experts and were obtained with available information from the UNEP GEMS/Water (the Global Environment Monitoring System for Water of the United Nations Environment Programme), which occupies a unique position to monitor the inland water quality, as well as maintains a global water quality database called GEMStat, which has millions of entries for lakes, rivers and groundwater systems that come from close to 3200 monitoring stations in more than 100 countries.

The units of the five parameters are different; hence, they require normalization. Once normalized, they are considered of equal weight, and the results are averaged to obtain a global water quality index ranging from 0 to 1 . Transformation of the results for the five parameters is performed differently in each case using the categorical scale method. In the case of the $\mathrm{pH}$, the raw data were converted into a proximity scale of target values by Eq. 4 below in which the proximity to target (PTT) indicates the target value; subindices $\mathrm{i}$ and $j$ denote the state and monitoring station, respectively, and max or min denotes the maximum or minimum observed. The objective value of a parameter is denoted by $t[15]$ :

$$
P H_{i, j}^{P T T}=\left\{\begin{array}{c}
1, t_{1}^{P H} \leq P H_{i, j} \leq t_{2}^{P H} \\
1-\frac{t_{1}^{P H}-P H_{i, j}}{t_{1}^{P H}-P H_{\min }}, P H_{i, j}<t_{1}^{P H} \\
1-\frac{P H_{i, j}-t_{2}^{P H}}{P H_{\max }-t_{2}^{P H}}, P H_{i, j}>t_{2}^{P H}
\end{array}\right.
$$

The National Water Commission of Mexico (CONAGUA by its initials in Spanish), nonetheless, does not publish information related to the monitoring of these five parameters. That is why in this study, information was used from the following four waterquality parameters at the state level from 2015 that are monitored by CONAGUA at 4999 sites around Mexico [44]:

- The 5-day biochemical oxygen demand (BOD5) $[\mathrm{mg} / \mathrm{L}]$

- Chemical oxygen demand (COD) $[\mathrm{mg} / \mathrm{L}]$

- Total suspended solids (TSS) $[\mathrm{mg} / \mathrm{L}]$

- Total dissolved solids (TDS) [mg/L]

The information from all 4999 CONAGUA stations was considered. As was the case in the methodology proposed by [15], normalization of these parameters, which have the same unit of measurement, $\mathrm{mg} / \mathrm{L}$, was carried out in accordance with Eq. 5. In this case, subindices $i$ and $j$ denote the state and monitoring station, respectively.

$$
B O D 5_{i, j}^{P T T}=\left\{\begin{array}{c}
1, B O D 5_{i, j} \leq t^{B O D 5} \\
1-\frac{B O D 5_{i, j}-t^{B O D 5}}{B O D 5_{\max }-t^{B O D 5}}, B O D 5_{i, j}>t^{B O D 5}
\end{array}\right.
$$

Winsorization was applied before employing Eq. 5, limiting the extreme values in the data to reduce the effect of possibly spurious outliers.

\section{Flood index (safety)}

The flood index expresses the flooding frequency for a given period, the same as in [3]. In Mexico, information is available from public reports on hydrometeorological phenomena per municipality for the period of 2000 2016, published by CONAGUA [45]. The results require normalization, from 2003 to 2017 in our case, following the same water quality criteria [15]. The safety (against flood) index $S$ was computed with the following equation:

$$
S=\frac{\left(\sum_{1}^{N} D\right) / n}{N}
$$

where $D$ is the number of flood events per municipality in each state, $N$ is the number of municipalities in the state, and $n$ is the number of years in the registered period.

The weights of the water-quality and safety indicators in the index are 50 and 50\%, respectively, as shown in Eq. 7:

$$
I_{C S}=(0.5 C)+(0.5 S)
$$

where $C$ is the water-quality index and $S$ is the index of safety against flooding.

\section{Water management}

The water management index is comprised of the world governance index with a weight of $70 \%$, the transboundary legal framework (15\%), and the hydropolitical transboundary tension (15\%). This management index affects the other three criteria of the global water security index (availability, accessibility, and quality and safety). Primarily, the world governance index is applicable at the country scale and evaluates voice and accountability, political stability and absence of violence, government effectiveness, regulatory quality, rule of law, and corruption control.

\section{World governance index}

The world governance index (WGI) [17] establishes that governance consists of the traditions and institutions by which authority in a country is exercised. This includes the process by which governments are elected, 
monitored and replaced, the capacity of the government to effectively formulate and implement sound policies, and the respect of citizens and the state for the institutions that govern the economic and social interactions among them [17].

Figure 1 defines the six variables of the world governance index and shows its variation for Mexico, in percentiles ranging from 0 to 100, from 2005 to 2015 [17]. Government effectiveness and regulatory quality increased slightly, but the other four indicators, voice and accountability, political stability, absence of violence, rule of law, and control of corruption, decreased.

In the absence of information disaggregated per Mexican state for these 6 variables, their values were obtained from [17] at the country level for 2015. Equal weighting was given to each of these variables in computing WGI.

\section{Transboundary legal framework (LF)}

This indicator maps the presence of key international legal principles in transboundary treaties, providing a first overview of the set of principles underlying, at least on paper, transboundary water relationships. The transboundary legal framework is based on the assumption that the governance of a transboundary basin is guided by (among other things) the legal agreements in place and that these agreements provide a framework for the allocation of resources for different uses between countries [46]. It is of clear importance for Mexico, a country that shares river basins and aquifers with other counties along its boundaries, namely, with the United States of America to the north and with Guatemala and Belize to its south.

Values of the transboundary legal framework indicator, along with those of the other indicators, are computed and published in the Transboundary Waters Assessment Programme (TWAP) report of the United Nations
Environment Programme (UNEP) [46] for 286 transboundary river basins that span 151 countries, among them Mexico. According to the TWAP methodology, those values range from zero (very high risk) to 7 (very low risk). Table 2 summarizes the values corresponding to the Mexican border states, taken from the maps presented in [46]. For the rest of the states (the nonborder states), a score of 7 is assumed, corresponding to a very low risk.

For normalization purposes, the values in Table 2 were divided by 7 .

\section{Transboundary hydropolitical tension (TT)}

Similarly, the TWAP hydropolitical tension indicator narrows down the analysis to the formal provisions that exist in transboundary basins to lessen the tensions arising from the construction of water infrastructure-a common source of dispute between countries-and factors in other circumstances that could exacerbate transboundary hydropolitical tensions stemming from basin development [46]. Its value ranges from 1 (very low risk) to 5 (very high risk).

Table 3 lists the values corresponding to the Mexican border states, derived from the maps presented in [46]. For the rest of the states (the nonborder states), a score of 1 is assumed, corresponding to a very low risk.

The management index, according to the aggregation of its three indicators and their weights, can be determined by Eq. 8:

$$
I_{A d}=(0.7 W G I)+(0.15 L F)+(0.15 T T)
$$

Table 4 and Fig. 2 explain the proposed conceptual framework and process for obtaining the GWSI at the state level, which is in fact an adaptation of the methodology described by [3] that integrates physical and

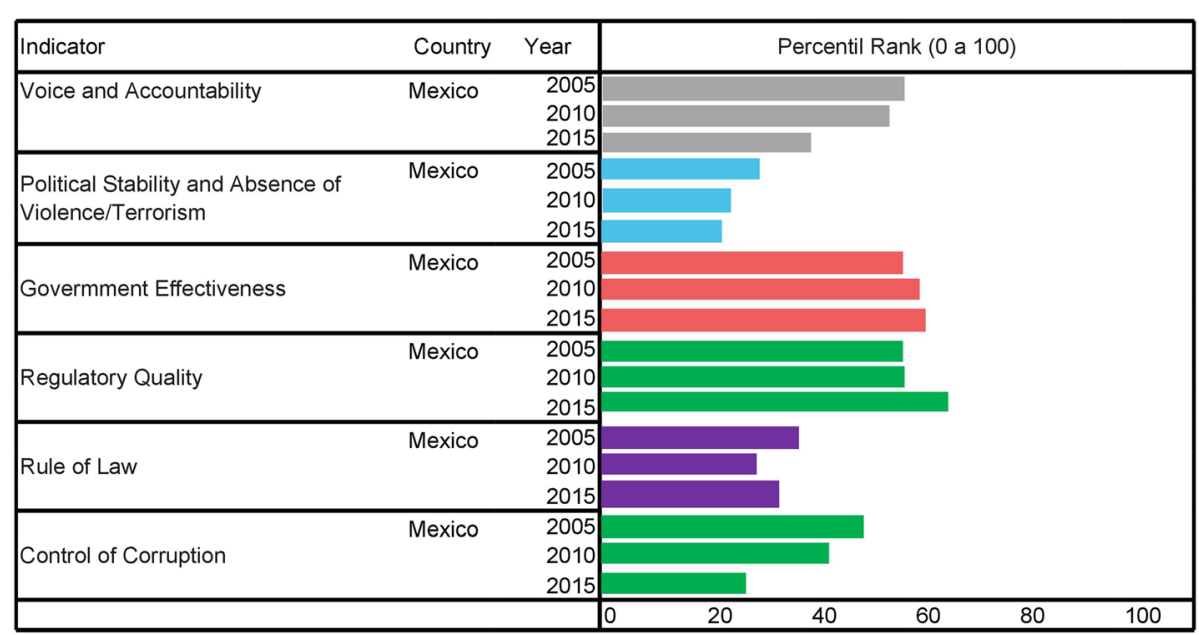

Fig. 1 World governance index from 2005 to 2015 for Mexico. Source: [17] 
Table 2 Transboundary legal framework indicator for Mexican border states. Source: [46]

\begin{tabular}{ll}
\hline State & Score (from 0 to 7) \\
\hline North boundary & \\
Baja California & 5.6 \\
Sonora & 3.5 \\
Chihuahua & 5.6 \\
Coahuila & 5.6 \\
Nuevo León & 5.6 \\
Tamaulipas & 5.6 \\
South boundary & \\
Chiapas & 1.345 \\
Tabasco & 1.345 \\
Campeche & 1.345 \\
Quintana Roo & 0.19 \\
\hline
\end{tabular}

socioeconomic dimensions but with a particular data collection and processing approach used, including normalization and aggregation. Each of the four criteria of the GWSI, i.e., availability, accessibility, safety and quality, and management, is in turn integrated by the indicators shown in the flowchart in Fig. 2. Each indicator and criterion is weighted to express its relative contribution to the GWSI. The same weights that were defined by [3] were also used, as shown in the flow chart. The highest relevance is assigned to the availability (45\%), compared to the accessibility (20\%), safety and quality (20\%), and management (15\%).

The data for each of the indicators are collected from different sources, and as the indicator values have different units of measurement, they are normalized from 0 to 1 to be compared with other indicators. Official annual data were used for the availability, accessibility, and quality and

Table 3 Transboundary legal framework indicator for Mexican border states. Source: [46]

\begin{tabular}{ll}
\hline State & Score (from 0 to 5) \\
\hline North boundary & \\
Baja California & 1.25 \\
Sonora & 2.00 \\
Chihuahua & 1.25 \\
Coahuila & 1.25 \\
Nuevo León & 1.25 \\
Tamaulipas & 1.25 \\
South boundary & \\
Chiapas & 4.00 \\
Tabasco & 4.00 \\
Campeche & 4.00 \\
Quintana Roo & 3.00 \\
\hline
\end{tabular}

safety, mostly from 2015. For management, the same data sources used by [3] were employed, although the governance country level data are from 2015 instead of 2010 . Then, the GWSI is calculated by aggregating the indicators by simple additive weighting (SAW). The detailed adaptation procedure at the state level (instead of at the country level) is described above in the respective sections for each GWSI component.

In the final result, the states were classified in water security terms using the Jenks statistical clustering algorithm [47]. This algorithm identifies natural data groupings to create classes that minimize the variability within each group and maximize the variability among groups in an attempt to create more homogeneous classes. The resulting classes are such that there is a maximum variance among the individual classes and the least variance within each class. QGIS software, in which the Jenks algorithm is incorporated, was used to establish the categorization.

The weighting used is subjective; therefore, as recommended in [3], in future practical applications of this adapted methodology, it is convenient to conduct validation meetings in each of the states, in which local experts can formulate proposals for improvement, including adjustments to the weights of all criterions and their indicators. Although it is clear that availability must be assigned the greatest weight, it is also true that the management of water resources impacts its preservation, and therefore, it must be evaluated whether a management weight of $15 \%$ is adequate.

\section{Handling and integration of the information in a GIS}

In light of the amount of data that has to be processed for the creation and mapping of the indices, it is necessary to use a geographical information system (GIS) that permits the capture, analysis, storage, consultation and presentation of data in reference to each state. The process was carried out using the open QGIS platform.

\section{Results}

Figure 3 shows a map of the Mexican states in terms of the GWSI calculated with the methodology in this study as a first approximation based on the available data. The states in which the situation is critical, according to the GWSI, are Sonora, Baja California and Guanajuato, followed by Mexico City, Colima, Aguascalientes and Sinaloa.

Table 5 lists, per Mexican state, its population, percentage of urban area, and state marginalization degree (SMD) expressing the general economic condition of the state [48]. From the GWSI analysis, there are seven Mexican states with values between 0.46 and 0.52 , which, according to the classification obtained, is considered a low GWSI index. These 
Table 4 Hierarchy and weights for obtaining the state-level global water security index in our study

\begin{tabular}{|c|c|c|c|}
\hline \multicolumn{4}{|l|}{ Global water security index } \\
\hline $\begin{array}{l}\text { Availability } \\
45 \%\end{array}$ & $\begin{array}{l}\text { Accessibility } \\
20 \%\end{array}$ & Safety and quality $20 \%$ & $\begin{array}{l}\text { Management } \\
15 \%\end{array}$ \\
\hline $\begin{array}{l}\text { a) WSI (70\%). } \\
W S I=\frac{W_{w}}{A_{w}-E_{w}} \\
\text { where: } \\
W_{w} \text { : water withdrawal } \\
A_{w} \text { : water availability (renewable) } \\
\text { and } \\
E_{w} \text { : environmental flow } \\
\text { requirements; in \% } R_{w} \text {, as } \\
\text { determined by Mexican standard } \\
\text { NMX-AA-159-SCFI-2012, which es- } \\
\text { tablishes the procedure for environ- } \\
\text { mental flow determination in } \\
\text { hydrological basins. } \\
\text { b) Drought index (15\%). } \\
\text { As percentages of the municipalities } \\
\text { with drought and of the state } \\
\text { surface experiencing a drought, } \\
\text { according to the Mexico Drought } \\
\text { Monitor. } \\
\text { c) Groundwater depletion (15\%). } \\
\text { Ratio of groundwater extraction to } \\
\text { natural recharge plus return flows } \\
\text { from irrigation. }\end{array}$ & $\begin{array}{l}\text { a) Access to drinking water (60\%). } \\
\text { Percentage of the population with } \\
\text { access to sources of improved } \\
\text { drinking water, i.e., installation of } \\
\text { delivery points that protect water } \\
\text { from external contamination, } \\
\text { particularly fecal contamination. } \\
\text { Includes piped water to homes, } \\
\text { public hydrants, wells, protected } \\
\text { springs, and rainwater collection } \\
\text { systems. } \\
\text { b) Access to sanitation (40\%). } \\
\text { Percentage of the population with } \\
\text { access to improved sanitation } \\
\text { (whereby human excretions are } \\
\text { hygienically separated and is not } \\
\text { public, either private or shared). } \\
\text { Includes discharge to sewers, septic } \\
\text { systems, discharge latrines, simple } \\
\text { pit latrines or ventilated pit latrines. }\end{array}$ & $\begin{array}{l}\text { a) Water quality index (50\%). } \\
\text { Includes the following four water- } \\
\text { quality parameters monitored by } \\
\text { CONAGUA at } 4999 \text { sites around } \\
\text { Mexico: BOD5, COD, TSS, and TDS } \\
\text { b) Flood index (50\%). } \\
\text { Relative flooding frequency for a } \\
\text { given period, whereby the } \\
\text { information is available in public } \\
\text { reports on hydrometeorological } \\
\text { phenomena per municipality } \\
\text { published by CONAGUA. }\end{array}$ & $\begin{array}{l}\text { Expresses social and institutional } \\
\text { management issues such as water } \\
\text { planning and management, } \\
\text { economic policies, and others. } \\
\text { a) World governance index (70\%). } \\
\text { Includes voice and accountability, } \\
\text { political stability and absence of } \\
\text { violence, government effectiveness, } \\
\text { regulatory quality, rule of law, and } \\
\text { control of corruption } \\
\text { b) Transboundary legal framework } \\
\text { (15\%). } \\
\text { Expresses the range of treaties per } \\
\text { transboundary basin and their } \\
\text { associated risks of conflict. } \\
\text { c) Transboundary hydropolitical } \\
\text { tension (15\%). } \\
\text { Expresses the level of tension in } \\
\text { transboundary basins and the } \\
\text { associated risk levels. }\end{array}$ \\
\hline
\end{tabular}

states are Baja California, Sonora, Sinaloa, Colima, Aguascalientes, Guanajuato and Mexico City. The population of these seven states is on the order of 26.08 million inhabitants, which represents approximately $21.7 \%$ of the total population of Mexico. It should be noted that although the GWSI is low, the SMD in three of these states is also very low.

The states of Sonora, Baja California, Aguascalientes, and Guanajuato, according to Arreguín-Cortes [49] and
Ortega-Gaucin [50], are located in regions of Mexico that are most likely to suffer the effects of drought and in which water availability has become a problem due to the overexploitation of aquifers [49]. Mexico City, with a population close to 8.99 million inhabitants, and with $41.02 \%$ of its total area of $1487.48 \mathrm{~km}^{2}$ urbanized, faces the need to import water from other watersheds, thereby becoming a low-GWSI urban area in Mexico. On the other hand, two of the states with the highest GWSI

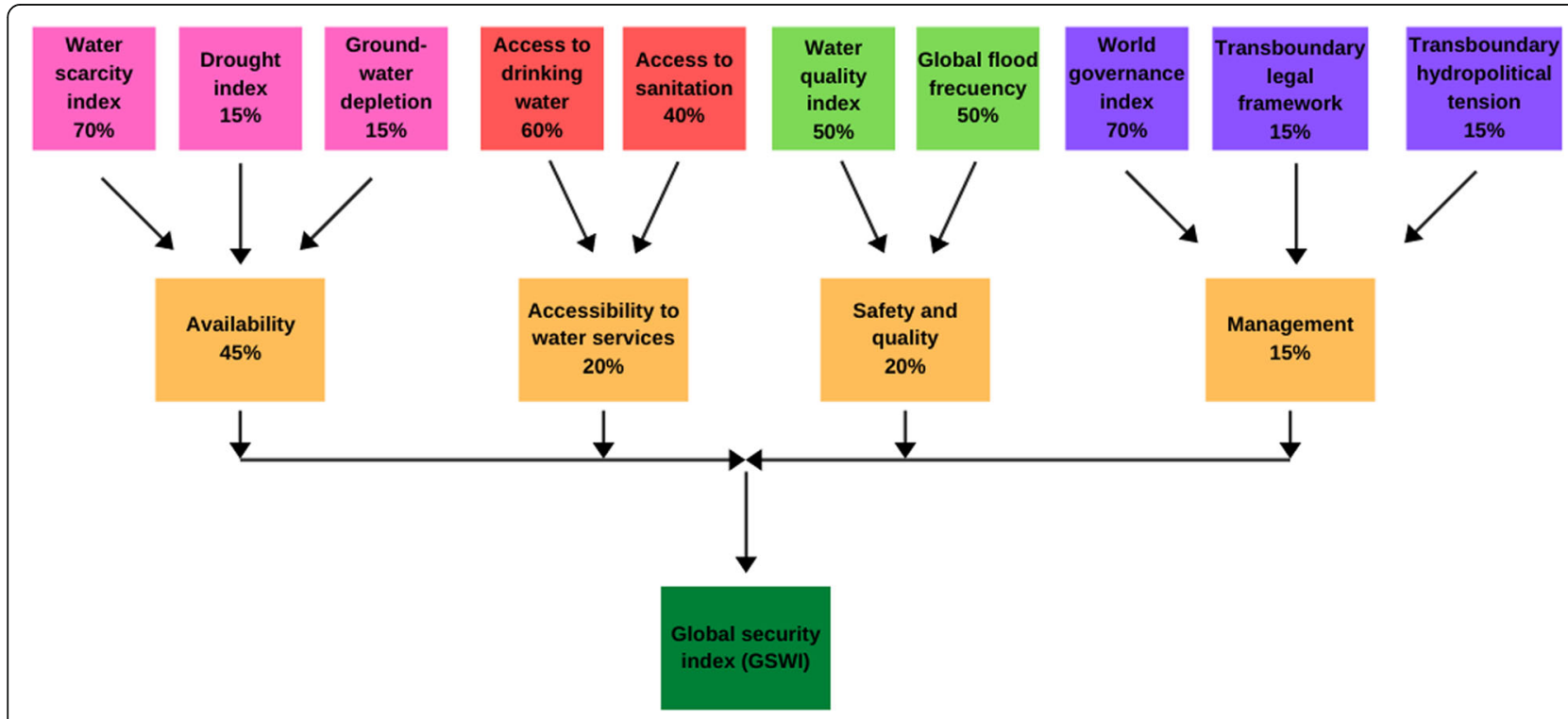

Fig. 2 Flow chart of the proposed procedure for obtaining the global water security index and respective component weighting 


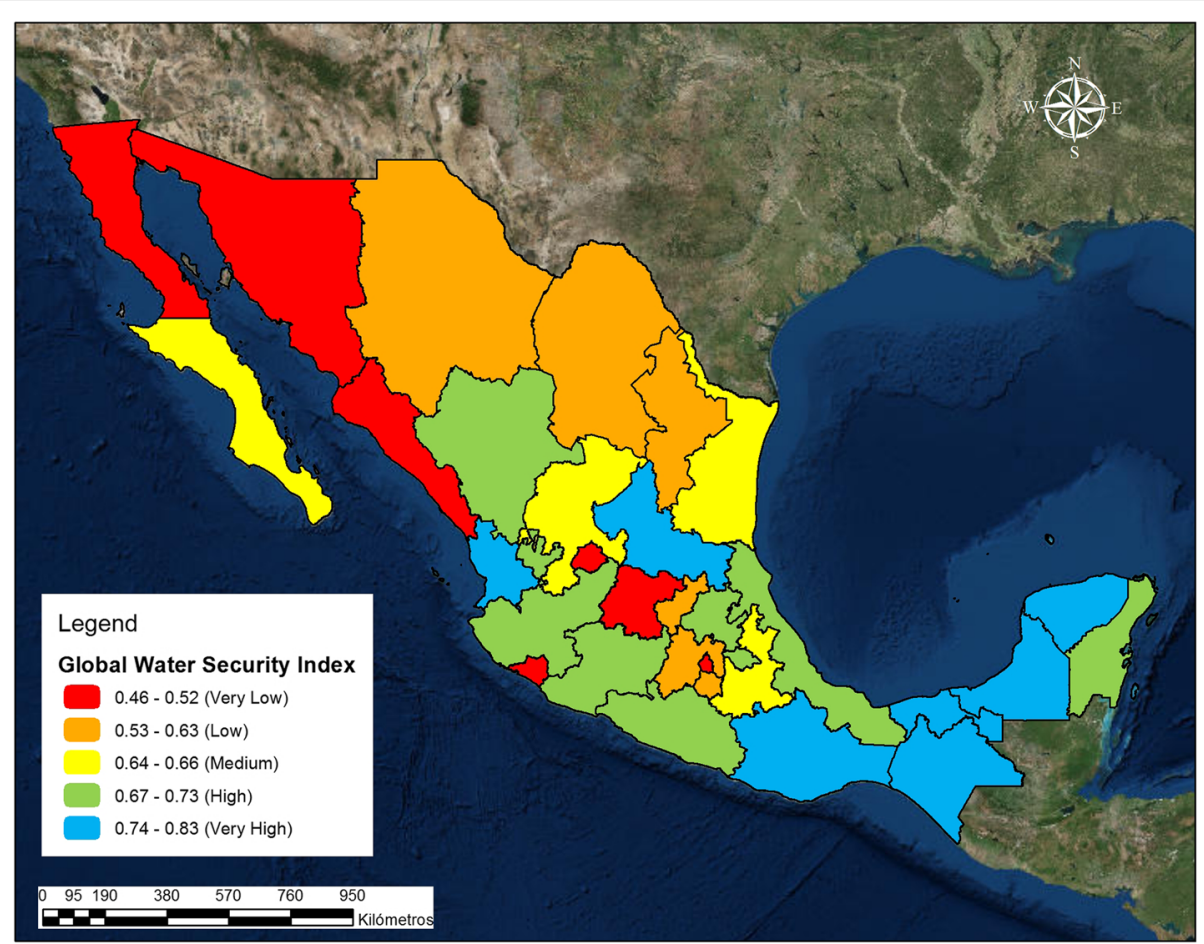

Fig. 3 Global water security index at the state level

(Campeche, Chiapas, Nayarit, Oaxaca, San Luís Potosí, Tabasco and Yucatán) have a very high SMD, and in one of these states, the SMD is high.

The urban area percentage provides a better interpretation of the results since the north of Mexico has areas with greater territorial extension but a smaller portion of the urbanized area where water security must be guaranteed, which is favorable for water security. The states of Aguascalientes and Mexico City have larger problems with respect to their urban area; on the other hand, the states of Yucatan and Nayarit are those that have a higher water security and are home to a larger population with respect to their extension per state.

\section{Sensitivity analysis}

The GWSI value obtained by the proposed methodology depends on the weights assigned to each of the four water security criteria, which in turn depend on the weights assigned to their respective components (Fig. 2). The GWSI also depends on the component values themselves, which normally carry some level of uncertainty. While in the present paper the same weights as those used in [3] were assumed (i.e., 45\% for availability, $20 \%$ for accessibility, $20 \%$ for safety and quality, and $15 \%$, for management), mainly for comparison purposes, it is important to investigate the capacity of GWSI to be robust to or independent of the arbitrary choice of the weights and input data uncertainty. A detailed sensitivity analysis of this kind is beyond the scope of this paper and will be considered in future work. Instead, at this stage of the study, a simple sensitivity analysis was carried out with respect to the weights of the four water security criteria. Numerical incremental analysis, also known as one-at-atime (OAT) analysis [51], was employed by changing one parameter at a time. The weight of one water security criterion was incrementally changed to higher and lower values, while maintaining those of the others at their baseline (nominal) values. Thereafter, the weight was returned to its nominal value, and the process was repeated for each of the other inputs in the same way. For each individual weight change, the weights of the other three criteria were adjusted with the following equation [52]:

$$
w_{j}^{\prime}=\frac{1-w_{p}^{\prime}}{w_{p}} w_{j}
$$

where $w_{j}^{\prime}$ is the new weight, $w_{p}$ is the original weight of the criterion to be adjusted and $w_{p}$ ' is the value after the criterion was adjusted. In this way, the sum of the weights was always equal to 100 . Figure 4 depicts the graphical analysis results for the Mexican state of Aguascalientes. An increment of 5\% was used. Table 6 lists the weights used, above and below the nominal weights.

The input values for that particular Mexican state are availability $=0.416, \quad$ accessibility $=0.986, \quad$ safety and 
Table 5 Indicators per Mexican state

\begin{tabular}{|c|c|c|c|c|c|c|}
\hline No. & GWSI range & State & Area $\left(\mathrm{km}^{2}\right)$ & Population (inhabitants) & Percentage of the urban area & SMD \\
\hline 1 & Very high & Campeche & $57,679.11$ & 902,250 & 0.450 & High \\
\hline 2 & & Chiapas & $73,594.23$ & $5,228,711$ & 0.729 & Very high \\
\hline 3 & & Nayarit & $27,771.26$ & $1,188,671$ & 1.016 & Medium \\
\hline 4 & & Oaxaca & $93,948.71$ & $3,976,297$ & 0.726 & Very high \\
\hline 5 & & San Luis Potosí & $60,462.75$ & $2,723,772$ & 0.743 & High \\
\hline 6 & & Tabasco & $24,701.82$ & $2,400,967$ & 0.625 & Medium \\
\hline 7 & & Yucatán & $39,663.36$ & $2,102,259$ & 1.857 & High \\
\hline 8 & Very low & Aguascalientes & 5559.73 & $1,316,032$ & 3.148 & Low \\
\hline 9 & & Baja California & $73,565.74$ & $3,348,898$ & 1.291 & Very low \\
\hline 10 & & Colima & 5752.31 & 715,095 & 0.488 & Very low \\
\hline 11 & & Ciudad de México & 1487.48 & $8,985,339$ & 41.022 & Very low \\
\hline 12 & & Guanajuato & $30,336.15$ & $5,864,777$ & 1.975 & Medium \\
\hline 13 & & Sinaloa & $56,801.37$ & $2,977,104$ & 1.099 & Medium \\
\hline 14 & & Sonora & $180,936.70$ & $2,874,391$ & 0.413 & Low \\
\hline 15 & High & Durango & $122,161.17$ & $1,759,848$ & 0.265 & Medium \\
\hline 16 & & Guerrero & $63,608.95$ & $3,542,204$ & 0.733 & Very high \\
\hline 17 & & Hidalgo & $20,653.08$ & $2,862,970$ & 1.379 & High \\
\hline 18 & & Jalisco & $77,952.90$ & $7,880,539$ & 1.542 & Low \\
\hline 19 & & Michoacán de Ocampo & $58,300.20$ & $4,599,104$ & 1.496 & High \\
\hline 20 & & Quintana Roo & $42,659.91$ & $1,505,785$ & 1.212 & Medium \\
\hline 21 & & Tlaxcala & 3981.92 & $1,274,227$ & 1.618 & Medium \\
\hline 22 & & Veracruz & $71,470.07$ & $8,127,832$ & 1.344 & High \\
\hline 23 & Low & Chihuahua & $246,972.63$ & $3,569,479$ & 0.492 & Low \\
\hline 24 & & Coahuila de Zaragoza & $150,670.31$ & $2,961,708$ & 2.256 & Low \\
\hline 25 & & México & $22,227.39$ & $16,225,409$ & 4.848 & Low \\
\hline 26 & & Morelos & 4861.89 & $1,912,211$ & 6.667 & Medium \\
\hline 27 & & Nuevo León & $63,615.16$ & $5,131,938$ & 1.657 & Very low \\
\hline 28 & & Querétaro & $11,603.60$ & $2,043,851$ & 1.984 & Low \\
\hline 29 & Medium & Baja California Sur & $73,964.04$ & 718,384 & 0.370 & Low \\
\hline 30 & & Puebla & $34,119.27$ & $6,183,320$ & 1.876 & High \\
\hline 31 & & Tamaulipas & $79,404.09$ & $3,453,525$ & 1.216 & Low \\
\hline 32 & & Zacatecas & $74,502.48$ & $1,581,575$ & 0.479 & Medium \\
\hline
\end{tabular}

quality $=0.700$, and management $=0.577$. For those values and the nominal criterion weights (45\% for availability, $20 \%$ for accessibility, $20 \%$ for safety and quality, and $15 \%$, for management), a GWSI of 0.614 is obtained, and the results in Fig. 4 deviate from that value for each incremental weight variation. The GWSI is observed to deviate by less than $7 \%$, demonstrating that the index is robust with respect to changes in the weights. As shown in the figure, the sensitivity is higher for the availability and accessibility components, explained by the high nominal weight of the former and the high (close to one) value of the latter.

\section{Discussion}

In this work, the methodology proposed in [3] for obtaining the global water security index was adapted to the state level in Mexico, with data mainly from CONAGUA, as well as international data for the management component. The authors of [3] propose that the index can be applied at the global scale so that the water security performance of each country can be determined, thus establishing a worldwide water security benchmark that can facilitate international cooperation. In this index, four criteria or interrelated physical and socioeconomic factors with prioritized attention are contained, 


\section{GWSI sensitivity for Aguascalientes}

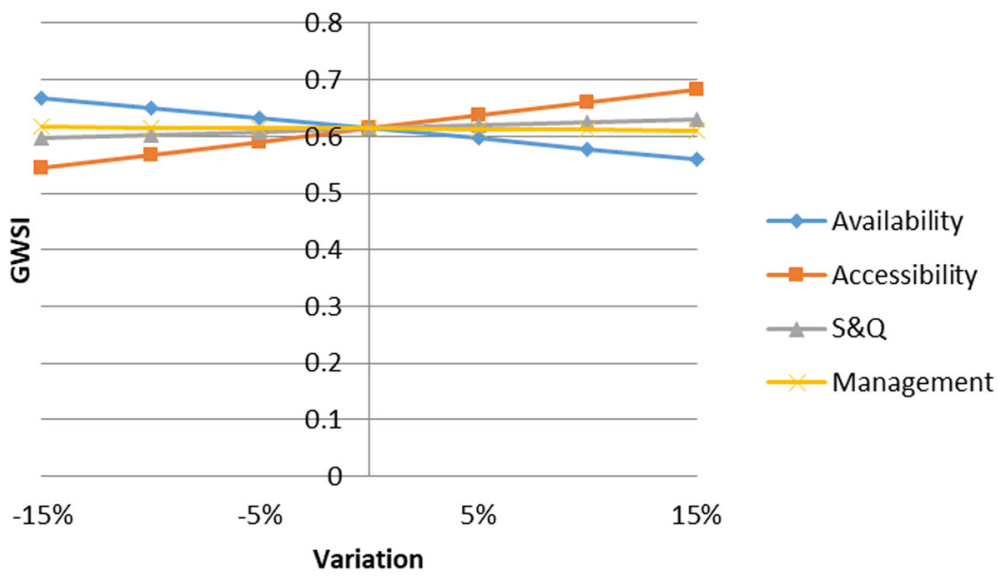

Fig. 4 Sensitivity analysis for the state of Aguascalientes

namely, water availability, access to sanitation and drinking water, safety against extreme hydrometeorological events, and management. Within the management criterion, there is a world governance index composed of six indicators that vary in percentile range from 0 to 100 .

The water quality parameters employed in the present study for computing the water quality index are different from those used in $[3,15]$, mainly because the water quality parameters used in [3] are not monitored and officially published in Mexico. No attempt has been made to analyze how close the results would be to those obtained by the methodologies in $[3,15]$. While this could be examined in future work, the water quality index computed in the present study uses data from 4999 stations across Mexico (the index proposed in [3] uses data from 3200 stations around the globe), thus being country specific and more representative for the study purposes.

The Mexican states that have a higher probability of being affected by drought are those found in the northwest of Mexico (Baja California, Baja California Sur, Sonora, and Sinaloa), in the central north (Chihuahua,

Table 6 Weights used in the sensitivity analysis

\begin{tabular}{lllll}
\hline Variation & Availability & Accessibility & S\&Q & Management \\
\hline $15 \%$ & $60 \%$ & $35 \%$ & $35 \%$ & $30 \%$ \\
$10 \%$ & $55 \%$ & $30 \%$ & $30 \%$ & $25 \%$ \\
$5 \%$ & $50 \%$ & $25 \%$ & $25 \%$ & $20 \%$ \\
$0 \%$ & $45 \%$ & $20 \%$ & $20 \%$ & $15 \%$ \\
$-5 \%$ & $40 \%$ & $15 \%$ & $15 \%$ & $10 \%$ \\
$-10 \%$ & $35 \%$ & $10 \%$ & $10 \%$ & $5 \%$ \\
$-15 \%$ & $30 \%$ & $5 \%$ & $5 \%$ & $0 \%$ \\
\hline
\end{tabular}

Coahuila, Durango, the northern part of Nuevo León and Tamaulipas), central west (Nayarit, Jalisco, Michoacán, and Guanajuato), and the southeast (Tabasco, Chiapas, Yucatán, Campeche and Quintana Roo). These results coincide with historical drought logs since states in the national territory that have historically been more affected by droughts are located in the Mexican highlands. These states experience the aggravated effect of being located in zones that are characterized by being preeminently arid, which is why their populations and distinct economic activities are highly vulnerable due to the water scarcity provoked by droughts, given that in the majority of these states, extremely dry and semidry climates predominate. Although the vast majority of the most vulnerable states and municipalities that have the highest drought risk are found in the north in the Mexican highlands, even southern states such as Guerrero, Oaxaca, Chiapas, and Tabasco (which are typically characterized as being rainy) contain municipalities that have a high degree of drought vulnerability and are also severely affected by this phenomenon, especially in those years in which El Niño manifests itself, as was the case in 2015. That year, many municipalities in Chiapas Guerrero, Oaxaca and Tabasco, mainly, had declared a state of emergency due to drought, and the agriculture and livestock sectors experienced significant losses.

Water security is transversal in every aspect of economic development. People assign meaning to the concept of water security depending on the scale and the particular context in which it is applied. Water security can never be fully reached because physical and economic conditions are in constant flux, which requires constant adaptation [53]. There is no single solution to increase water security. Moreover, solutions must be adapted to the local conditions of each country, basin, 
city, project or administration area. Water security and integrated water resources management (IWRM) are symbiotic: the adaptive management policies contained in IWRM help to improve water security from the national level to the local level. Water security should be seen as the goal of IWRM; that which cannot be measured, cannot be managed, and thus water security measurement is fundamental to its enhancement.

The task of improving water security implies responding not only to the risks that are observed in the present but also adequately responding to the new challenges that occurring in the sector. Known challenges to overcome in reaching water security are water scarcity, water pollution, adverse effects of hydrometeorological events, growing water conflicts and environmental deterioration of basins and aquifers [1-9, 24, 25]. The methodology proposed in this paper, applied at the state level in Mexico, contributes to a better understanding of the implications of water security and has a high potential to track changes over time to inform IWRM practices and define public policies.

In this first study on water security indices in Mexico, the environmental flow volume was obtained mainly according to a custom official Mexican standard that establishes the procedure for environmental flow determination in hydrological basins, named NMX-AA-159-SCFI2012 [30]. The simple recognition in that norm whereby the environmental water requirements between basins depend on the context of both the water demand and ecological importance represents, in fact, a major Mexican advance towards water security. In future work, the application of other approaches, for example, the one proposed in [54], which considers more updated environmental water science and management approaches, can also be assessed.

\section{Conclusions}

The main limitation for the construction of an index that adheres to the reality of Mexico and clearly reflects the national situation is the lack of information. In this area, there is an absence of measurement, follow-up and data processing, asymmetrical information at different aggregate levels (state and municipal), and discretional handling of existing information. On the other hand, a complication of information integration is determining the degree of benefit attributed to water security given the complexity of the problem.

In regard to the components that were analyzed to create the management indicator, it can be conclusively stated that they are implicit within the considered indicators and occur in transversal form. In the future, it is recommended to incorporate information relative to the authorized budgets and their effective employment in states related to flood control, droughts, water treatment, improved drinking water services, etc--actions that directly strengthen water security in Mexico. For the application of the GWSI at the state level, there is annual information available mainly from CONAGUA, as well as international data in the management component. The main difficulty in integrating aspects such as water governance, institutional (effectiveness) coordination and environmental water requirements lies in the lack of information and monitoring of those variables that normally are not measured in Mexico. It would be desirable to determine such indicators, available at the country level, for each of the states. The future challenges include obtaining relevant real and documented information for the different levels of government, as well as an authority responsible for the monitoring and recording of institutional coordination and effectiveness, a role that could be fulfilled by river basin councils.

Finally, the methodology proposed in this paper may serve as an example of how to assess water security, at least as a first approximation, using mainly free and officially published information, combined with international comparative country information, especially for countries where such information is limited.

\section{Abbreviations}

BOD5: 5-day biochemical oxygen demand; COD: Chemical oxygen demand; CONAGUA: National Water Commission of Mexico (from Comisión Nacional de Agua in Spanish); DO: Dissolved oxygen; GIS: Geographical information system; GWSI: Global water security index; HR: Hydrological region;

IWRM: Integrated water resources management; LF: Transboundary legal framework; PCR-GLOBWB: PCRaster GLObal Water Balance hydrological model; PTT: Proximity to target; TDS: Total dissolved solids; TSS: Total suspended solids; TT: Transboundary hydropolitical tension;

TWAP: Transboundary Waters Assessment Programme; UNEP: United Nations Environment Programme; UNEP GEMS: United Nations Environment Programme Global Environment Monitoring System; WGl: World governance index; WSI: Water scarcity index

\section{Acknowledgements}

Not applicable.

\section{Authors' contributions}

Felipe I. Arreguín Cortés and J. Raúl Saavedra Horita participated in the Project conceptualization. Velitchko G. Tzatchkov and Petronilo E. Cortez Mejía developed the proposed methodology. J. Manuel Rodríguez Varela and Velitchko G. Tzatchkov did the investigation. Velitchko G. Tzatchkov drafted the manuscript. Óscar J. Llaguno Guilberto developed the GIS software application and visualization. Arizabeth Sainos Candelario participated in the data curation. All authors read and approved the final manuscript.

\section{Funding}

Not applicable. This research received no external funding.

\section{Availability of data and materials}

The datasets supporting the conclusions of this article are directly accessible, in an interactive way, on the http://172.16.2.211/ish/ homepage and public repository.

Ethics approval and consent to participate Not applicable.

Consent for publication

Not applicable. 


\section{Competing interests}

The authors declare that they have no competing interests.

\section{Author details}

${ }^{1}$ National Autonomous University of Mexico, Institute of Engineering, Circuito Escolar, Ingeniería S/N, C.U., CoyoacánCircuito Escolar, Ingeniería S/N, C.U., Coyoacán, 04510 Mexico City, Mexico. ${ }^{2}$ Independent advisor, Mexico City, Mexico. ${ }^{3}$ Mexican Institute of Water Technology, Paseo Cuauhnahuc 8532, Col. Progreso, 62550 Jiutepec, Morelos, Mexico.

Received: 24 January 2019 Accepted: 3 July 2020

Published online: 17 July 2020

\section{References}

1. Calow R, Tucker J. Achieving water security. Lesson form research in water supply, sanitation and hygiene in Ethiopia. London: Overseas Developments Institute (ODI); 2013. https://doi.org/10.3362/9781780447636.

2. Grey D, Sadoff C. Sink or swim? Water security for growth and development. Water Policy. 2007;9(6):545-71. https://doi.org/10.2166/wp.2007.021.

3. Gain AK, Giupponi C, Wada Y. Measuring global water security towards sustainable development. Environ Res Lett. 2016;11(12):2-13. https://doi.org/ 10.1088/1748-9326/11/12/124015.

4. Martinez Austria PF. Los retos de la seguridad hídrica (Challenges in water security). Tecnología y Ciencias del Agua. 2013;IV(5):165-80 (in Spanish). Available online: http://www.revistatyca.org.mx/ojs/index.php/tyca/article/ view/398/357. Accessed 4 Nov 2018.

5. Mason N, Roger C. Water security: from abstract concept to meaningful metrics. An initial overview of options. Working paper no. 357. London: Overseas Development Institute (ODI); 2012. Available online: https:/www.odi.org/sites/odi. org.uk/files/odi-assets/publications-opinion-files/7865.pdf. Accessed 4 Nov 2018.

6. Water Security for better lives. Organisation for Economic Co-operation and Development: OECD studies on water: OECD Publishing; 2013. https://doi. org/10.1787/22245081.

7. Water security and the global water agenda. A UN-water analytical brief. United Nation University. UN - Water; 2013. Available online: http://www.unwater.org/ publications/water-security-global-water-agenda/. Accessed 4 Nov 2018.

8. Norman E, Bakker K, Cook C, Dunn G, Allen D. Water security: introductory guide, creating of a strategic framework for water security in Canada as a tool for improving the water governance of drainage basins (2008-2012). Canada; 2010. ISBN 978-0-88865-698-8.

9. Increasing water security: a development imperative. Global Water Partnership; 2016. Available online: https://www.gwp.org/globalassets/ global/toolbox/publications/perspective-papers/02-increasing-watersecurity\%2D\%2D-a-development-imperative-2012.pdf. Accessed 4 Nov 2018

10. 17 goals to transform our world. UN; 2017. Available online: https://www.un org/sustainabledevelopment/. Accessed 4 Nov 2018.

11. Wada Y, Wisser D, Berkens FP. Global modeling of withdrawal, allocation and consumptive use of surface water and groundwater resources. Earth Syst Dynam. 2014;5:15-40. https://doi.org/10.5194/esd-5-15-2014.

12. Wada Y, van Beek LPH, Wanders N, Bierkens MFP. Human wate consumption intensifies hydrological drought worldwide. Environ Res Lett 2013;8(3). https://doi.org/10.1088/1748-9326/8/3/034036.

13. Wada Y, van Beek LPH, Weiland FCS, Chao BF, Wu Y-H, Bierkens MFP. Past and future contribution of global groundwater depletion to sea-level rise. Geophys Res Lett. 2012:1-6. https://doi.org/10.1029/2012GL051230.

14. Hsu A, Emerson J, Johnson L, Malik O, Schwartz JD, Allison A, Coplin K, Guy S, Lujan B, Hawkins N, Lipstein R, Miao W, Mala O, Levy MA, de Sherbinin A, Jaiteh M. Environmental performance index. Yale: Yale Center for Environmental Law and Policy, Yale University; 2014. Available online: http:// www.ciesin.org/documents/2014_epi report.pdf. Accessed 4 Nov 2018.

15. Srebotnjak T, Carr G, de Sherbinin A, Rickwood CJ. A global water quality index and hot-deck imputation of missing data. Ecol Indicators. 2011;17. https://doi.org/10.1016/j.ecolind.2011.04.023.

16. Center for Hazards and Risk Research at Columbia University. 2005. Available online: http://www.un-spider.org/links-and-resources/institutions/centerhazards-and-risk-research-chrr-columbia-university. Accessed 4 Nov 2018.

17. Kaufmann, D.; Kraay, A. Worldwide Governance Indicators. Natural Resource Governance Institute (NRGI) and Brookings Institution-World Bank Development Research Group. The World Bank Group. Available online: http:// info.worldbank.org/governance/wgi/index.aspx\#home. Accessed 18 Dec 2017.
18. Transboundary Waters Assessment Programme River Basins. Available online: http://twap-rivers.org/indicators/. Accessed 4 Nov 2018.

19. Chaves HML, Alipaz S. An integrated indicator for basin hydrology, environment, life, and policy: the watershed sustainability index. Water Resour Manag. 2007. https://doi.org/10.1007/s11269-006-9107-2 Springer Verlag.

20. van Ginkel KCH, Hoekstra AY, Buurman J, Hogeboom RJ. Urban water security dashboard: systems approach to characterizing the water security of Cities. ASCE 04018075-1. J Water Resour Plann Manage. 2018;144(12):04018075.

21. Makin, I.W. Arriens, W. L. and Prudente, N. Indicators for assessing national water security: Asia Water Development Outlook 2013. Proceedings from the GWP workshop: assessing water security with appropriate indicators. Available online: https://www.gwp.org/globalassets/global/toolbox/ publications/p763_gwp_proceedings_paper.pdf. Accessed 10 July 2020.

22. Shresthaa S, Aiharab Y, Bhattaraic AP, Bistac N, Kondod N, Futabaa K, Nishidaa K, Shindoa J. Development of an objective water security index and assessment of its association with quality of life in urban areas of developing countries. SSM-PopulationHealth. 2018;6:276-85, https://doi.org/ 10.1016/j.ssmph.2018.10.007.

23. Assefa YT, Babel MS, Sušnik J, Shinde VR. Development of a generic domestic water security index, and its application in Addis Ababa, Ethiopia. Water. 2019; 11:37. https://doi.org/10.3390/w11010037 www.mdpi.com/journal/water.

24. Oswald Spring U. Water security and national water law in Mexico. Earth Perspect. 2014;1(7):1-15. https://doi.org/10.1186/2194-6434-1-7.

25. Arreguín Fl, López M, Marengo H. Mexico's water challenges for the 21st century. in U. Oswald Spring (ed). Water Resources in Mexico: Scarcity, Degradation, Stress, Conflicts, Management, and Policy Hexagon Series on Human and Environmental Security and Peace. 2011;7:21-38. SpringerVerlag Berlin Heidelberg. https://doi.org/10.1007/978-3-642-05432-7_2.

26. Wada Y, van Beek LPH, Berkens FP. Modelling global water stress of the recent past: on the relative importance of trends in water demand and climate variability. Hydrol Earth Syst Sci. 2011:15(12):3785-808.

27. Smakhtin V. Low flow hydrology: a review. J Hydrol. 2001;240(3-4):147-86

28. Smakhtin V, Revenga C, Döll P. A pilot global assessment of enviromental water requirements and scarcity. Water International. 2004;29(3):307-17. https://doi.org/10.1080/02508060408691785.

29. Estadísticas del agua en México 2016. CONAGUA, Mexico (in Spanish) Available online: http://sina.conagua.gob.mx/publicaciones/EAM_2016.pdf. Accessed 4 Dec 2018

30. Norma mexicana NMX-AA-159-SCFI-2012 (in Spanish). Available online: https://www.gob.mx/cms/uploads/attachment/file/166834/NMX-AA-159SCFI-2012.pdf. Accessed 4 Dec 2018.

31. DOF. ACUERDO por el que se dan a conocer los resultados del estudio técnico de las aguas nacionales superficiales en las cuencas hidrológicas Río San Pedro....Región Hidrológica 12 Lerma-Santiago. México: Diario Oficial de la Federación; 2017. (in Spanish).

32. DOF. ACUERDO por el que se dan a conocer los resultados del estudio técnico de las aguas nacionales superficiales en las cuencas hidrológicas Salado, Cocula, Ahuacatlán, Atenguillo, Ameca Pijinto, .......... de la Región Hidrológica número 14 Río Ameca. México: Diario Oficial de la Federación; 2018. (in Spanish).

33. DOF-HR15. ACUERDO por el que se dan a conocer los resultados del estudio técnico de las aguas nacionales superficiales en las cuencas hidrológicas Río Ipala, Río Tomatlán A, Río Tomatlán B, Río San Nicolás A,.... Región Hidrológica 15 Costa de Jalisco. México: Diario Oficiaal de la Federación; 2018. (in Spanish).

34. DOF-19. ACUERDO por el que se dan a conocer los resultados del estudio técnico de las aguas nacionales superficiales en las cuencas hidrológicas Río Ixtapa 1....Regíon Hidrológica 19 Costa Grande de Guerrero. México: Diario Oficial de la Federación; 2017. (in Spanish).

35. DOF-20. ACUERDO por el que se dan a conocer los resultados del estudio técnico de las aguas nacionales superficiales en las cuencas hidrológicas Río Papagayo 1, Río Petaquillas..Región Hidrológica 20 Costa Chica de Guerrero. México: Diario oficial de la Federación; 2017. (in Spanish).

36. CONAGUA-25. ACUERDO por el que se dan a conocer los resultados del estudio técnico de las aguas nacionales superficiales en las cuencas hidrológicas Laguna Madre Norte..Regíon Hidrológica 25 San Fernando-Soto La Marina. México: Acuerdo; 2017. (in Spanish).

37. DOF. ACUERDO por el que se dan a conocer los resultados del estudio técnico de las aguas nacionales superficiales en las cuencas hidrológicas Río Salado, Río Grande, Río. Región Hidrológica 28 Papaloapan. México: Diario Oficial de la Federación; 2018. (in Spanish). 
38. DOF-30. ACUERDO por el que se dan a conocer los resultados del estudio técnico de las aguas nacionales superficiales en las cuencas hidrológicas Lagartero...Región Hidrológica 30 Grijalva-Usumacinta. México: Diario Oficial de la Federación; 2018. (in Spanish).

39. de la Lanza Espino G, Gonzalez Villela R, González IDM, Hernandez Pulido S. Caudal ecológico de ciertos ríos que descargan al Golfo de México y al Pacífico Mexicano. Revista Iberoamericana del agua. 2018:3-15 (in Spanish). RIBAGUA. 2018:5(1):3-15. https://doi.org/10.1080/23863781.2018.1442187.

40. DOF. Acuerdo por el que se da a conocer el resultado de los estudios de disponibilidad de las aguas superficiales.......que forman parte de la porción de la región hidrológica que comprende el Río Pánuco. México: Diario Oficial de la Federación; 2008. (in Spanish)

41. Monitor de Sequía en México (Drought monitor in Mexico. SMN. 2017. Obtained from: http://smn.cna.gob.mx/es/climatologia/monitor-de-sequia/ monitor-de-sequia-en-mexico. Accssed 4 Nov 2018

42. Ortega-Gaucin D, De la Cruz BJ, Castellano BHV. Vulnerabilidad, peligro y riesgo por sequía en el contexto del cambio climático en México. In: Lobato SR, Pérez CAA, editors. Agua y Cambio Climático. Jiutepec: Instituto Mexicano de Tecnología del Agua; 2018. p. 80-105. (in Spanish).

43. Handbook on Construction Composite Indicators-Methodology and user guide. Italy: Organisation for Economic Co-operation and Development. 2008. Available online: http://www.oecd.org/els/soc/ handbookonconstructingcompositeindicatorsmethodologyanduserguide. htm. Accessed 4 Nov 2018.

44. National Water Information System (NWIS). CONAGUA, Mexico. Obtained from: Water quality (nacional): http://sina.conaqua.gob.mx/sina/tema.php?tema= calidadAgua\&ver=mapa\&o=1\&n=nacional. Accessed 14 Dec 2017.

45. Sistema Nacional de Información del Agua. Declaratorias por fenómenos hidrometeorológicos (nacional) (National Water Information System. Declarations for hydrometeorological phenomena (national), CONAGUA, Mexico, Obtained from: https://www.gob.mx/conagua/acciones-yprogramas/sistema-nacional-de-informacion-del-agua-sina and http://sina. conagua.gob.mx/sina/tema.php?tema=declaratoriasFenomenos\&ver=mapa. Accessed 18 Dec 2017. (in Spanish).

46. Transboundary River Basins: status and trends. Nairobi: United Nations Environment Programme (UNEP); 2016. ISBN: 978-92-807-3531-4 Available online: http://geftwap.org/publications/river-basins-technical-report. Accessed 4 Nov 2018.

47. Jenks GF. The data model concept in statistical mapping. In: International yearbook of cartography, vol. 7; 1967. p. 186-90.

48. CONAPO Índice de marginación por entidad federativa y municipal, Consejo Nacional de Población. Available online: https://www.gob.mx/ conapo/documentos/indice-de-marginacion-por-entidad-federativa-ymunicipio-2015. Accessed 10 Nov 2019. (in Spanish).

49. Arreguín-Cortes Fl, Saavedra-Horita JR, Rodriguez-Varela JM, Tzatchkov VG, CortezMejia PE, Llaquno-Guilberto OJ, Sainos-Candelario A, Sandoval-Yoval L, OrtegaGaucin D, Mendoza-Cazares EY, Navarro-Barraza S. Municipal level water security indices in Mexico. SN Appl Sci. 2019;1:1194. https:/doi.org/10.1007/s42452-0191180-2 Springer Nature Journal, published online: 10 September 2019.

50. Ortega-Gaucin D, De la Cruz Bartolón J, Castellano Bahena HV. Drought vulnerability indices in Mexico. Water. 2018;10(11):1671.

51. Fox WP. Mathematical modeling for business analytics. Boca Raton: CRC Press, Taylor \& Francis Group; 2018.

52. Alinezhad A, Amini A. Sensitivity analysis of TOPSIS technique: the results of change in the weight of one attribute on the final ranking of alternatives. J Optim Ind Eng. 2011;7:23-8.

53. Van Beek E, Arriens WL. Water security: putting the concept into practice. Stockholm: Global Water Partnership; 2014.

54. Mekonnen M, Hoestra A. Four billion people facing severe water scarcity. Am Assoc Adv Sci. 2016:1-6. https://doi.org/10.1126/sciadv.1500323.

\section{Publisher's Note}

Springer Nature remains neutral with regard to jurisdictional claims in published maps and institutional affiliations.

\section{Ready to submit your research? Choose BMC and benefit from:}

- fast, convenient online submission

- thorough peer review by experienced researchers in your field

- rapid publication on acceptance

- support for research data, including large and complex data types

- gold Open Access which fosters wider collaboration and increased citations

- maximum visibility for your research: over $100 \mathrm{M}$ website views per year

At BMC, research is always in progress.

Learn more biomedcentral.com/submissions 